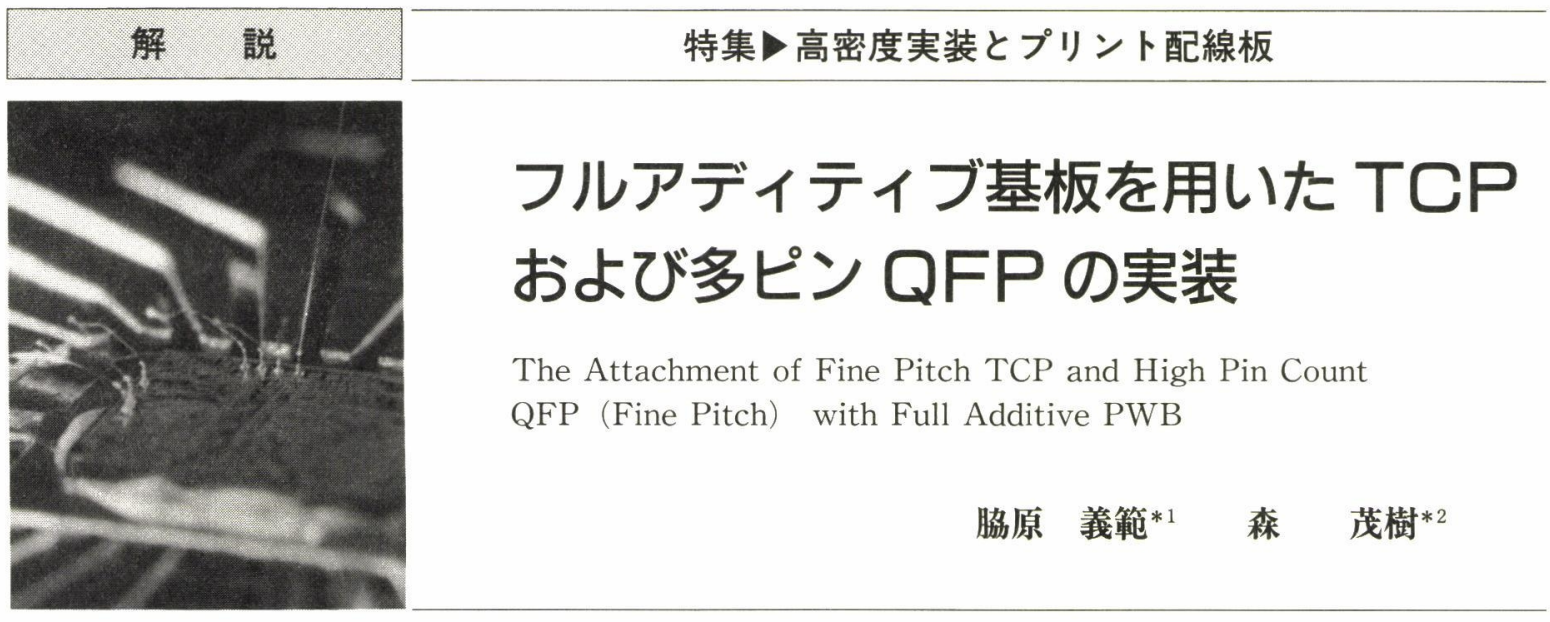

1.は じめに

近年の LSI チップの高機能, 高速化は, パッケージ ングや実装方法にも影響を与え，従来技術ではもはや LSI チップの性能が充分活かせない状況下にあるといえ る。このような中, これまで軍用，大型計算機などの分 野での応用に限られていた高密度実装技術が，さまざま な形態で，WS，通信機器などに採用され始めた。現在， この高密度実装技術において, 高歩留り, 高信頼性を得 るためのアプローチが関連業界において多様な角度から 行われている。しかし, 通常使用される部品のリードの ピッチが 0.5 ミリから 0.3 ミリをも切るようになると, 特に実装される基板側の性能をもはや無視できなくなる。

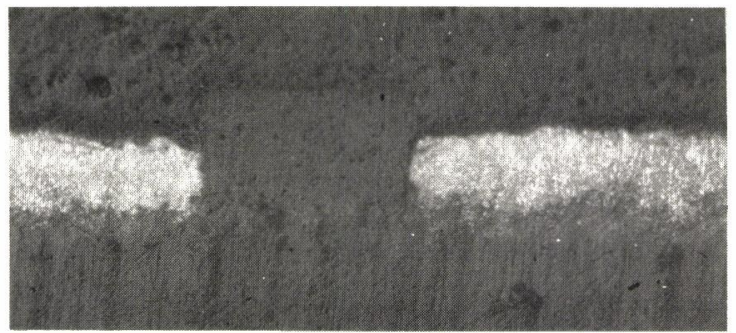

Fig.1 The cross section of full additive PWB.

*1 Yoshinori Wakihara

イビデン姝技術開発部MCM課／IBIDEN Co.,Ltd. 1st Section Technology \& Development Dept.

*2 Shigeki Mori

イビデン陎電子関連事業本部プリント板営業部／IBIDEN Co.,Ltd. PWB Development Dept.

32
当社はプリント配線板およびパッケージを中心とした 電子部品の製造，販売を行っているが，一方でこれら当 社製品への部品実装の検討をも積極的に進めている。

今回は, 当社のアディティブ基板を用いた 0.3 ミリピ ッチ以下の部品の高歩留り, 高信頼性実装のためのアプ ローチを示し, 将来の MCM-Lへの展開の可能性を示 すこととする。

\section{2. フルアディティブ基板の概要}

絶縁基板上に，無電解メッキなどによって導電性材料 を選択的に析出させて, 導体パターンを形成する方法を アディティブ法という。

フルアディティブ基板は，銅䇴なしの接着剤付き積層 板の上に感光性レジストパターンを形成し, 導体回路を 無電解銅メッキのみで形成するため, 導体厚さが均一で 平坦性がよい。また，メッキのつきまわり性が良いので スルホールの小径化に適している。

導体幅は，メッキレジスト精度のみに依存するため， 高精度な微細パターンの形成が可能である。さらに, 製 造プロセスがサブトラクティブ法より短く短納期化が可 能である等，すぐれた特徵がある。Fig.1に，フルアデ イティブ基板のパターン断面（長方形状）を示す。

\section{3. 供 試試 料}

\section{1 基 板}

$\mathrm{TAB}$ および $\mathrm{QFP}$ 実装に供するため, 以下の 2 種類 の試験基板を準備した（Fig. 2 )。

$\mathrm{TAB}$ 用，QFP 用の設計仕様を Fig.3 に示す。パッド 幅は, パッケージリード幅寸法, 実装精度を, パッド長 $S H M$ 会誌 


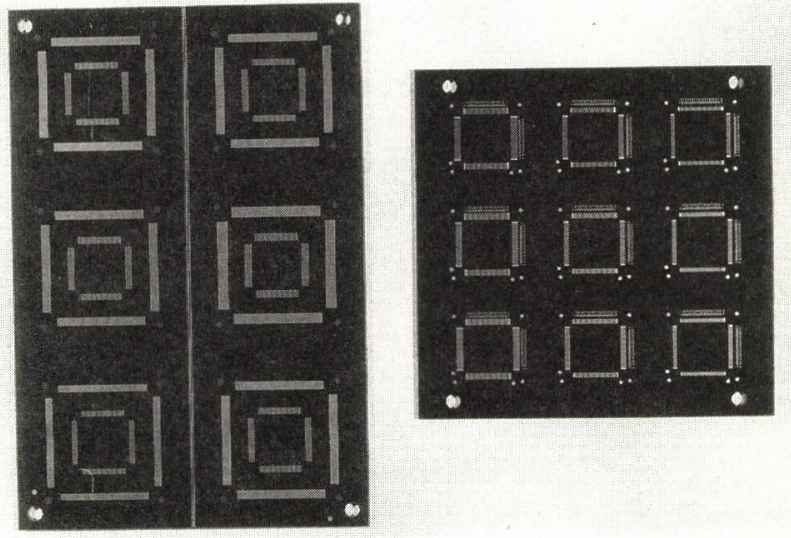

Fig.2
TAB : 0.2 ミリー 500 ピン

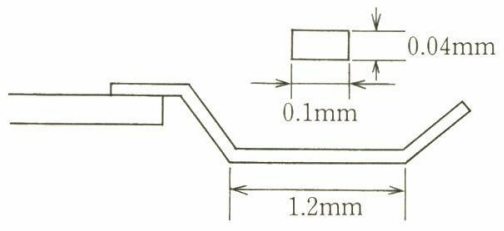

QFP : 0.3 ミリー 160 ピン

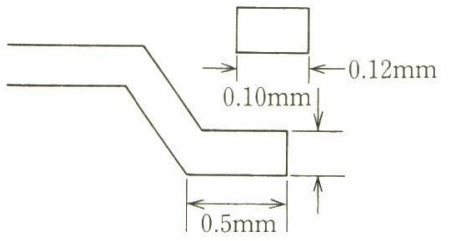

Fig. 4
TAB用 $(0.2$ ピッチ $)$

\begin{tabular}{|c|c|c|c|c|}
\hline & \multicolumn{3}{|c|}{ パッド幅 } \\
\hline & & 0.10 & 0.12 & 0.14 \\
\hline , & 1.60 & & 0 & \\
\hline ド & 1.90 & 0 & 0 & 0 \\
\hline 長 & 2.20 & & 0 & \\
\hline
\end{tabular}

QFP用 $\left(0.3 ヒ^{\circ} ッ チ\right)$

\begin{tabular}{|c|c|c|c|c|}
\hline \multicolumn{2}{|c|}{$\rightarrow$} & \multicolumn{3}{|c|}{ パッド幅 } \\
\cline { 2 - 5 }$\downarrow$ & & 0.10 & 0.14 & 0.16 \\
\hline \multirow{2}{*}{$\downarrow$} & 1.10 & $\bigcirc$ & $\bigcirc$ & $\bigcirc$ \\
\cline { 1 - 4 } & 1.40 & $\bigcirc$ & $\bigcirc$ & $\bigcirc$ \\
\cline { 2 - 5 } 長 & 1.80 & $\bigcirc$ & $\bigcirc$ & $\bigcirc$ \\
\hline
\end{tabular}

Fig.3

さは，リード長さ寸法，実装精度，適性はんだ量を考虑 に入れ設計した。

\subsection{TAB および QFP のリード形状}

Fig.4 に示す。

\section{3 実装のプロセス}

以下に実装のプロセスを示す。

\section{TAB 実装}

はんだペースト印刷（一文字印刷）ープリフラックス $\rightarrow$ エリフワー炉 $\rightarrow \mathrm{TAB}$ 実装 (熱圧着)

\section{QFP 実装}

はんだペースト印刷（メタルマスクでパッドへの個別 印刷 $) \rightarrow$ QFP 実装 $\rightarrow$ リロー炉

\section{4 はんだペースト}

共晶, フラックス含有量：11\%以下, 粒径：20～30 $\mu \mathrm{m}$

\section{4.はんだ処理}

3.で用意した基板へのはんだ供給について述べる。 Vol.9, No.6

\section{1 はんだ供給}

現状ファインピッチ対応の基板へのはんだの供給とし ては, 電解メッキ, 無電解メッキ, その他があるが, こ こではアディティブ基板の特徴を生かすため, TABも $\mathrm{QFP}$ もメタルマスクを使用して, SMT部品用パッド へのはんだ供給が同時に行えるはんだぺーストの“一文 字印刷法”を取った。

Fig.5に0.2 ミリピッチ TAB実装用パッドへのはん だ供給の結果を示す。Fig.6 とig.7には，0.3ミリピッ チの QFPの実装結果を，それぞれサブトラクティブ法 基板への実装結果の比較で示す。Fig.5より, リフロー

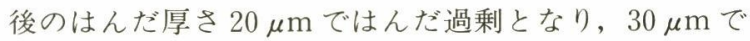
は平均 $10 \%$ 近いはんだブリッジ（ショート）が出てい ることがわかる。Fig.6と Fig.7より，アディティブ基

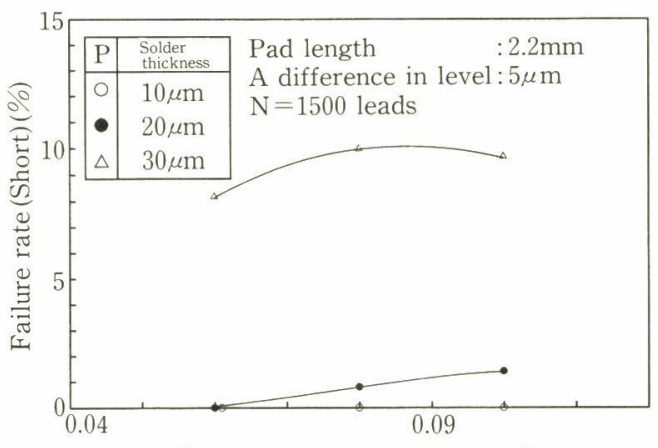

The distance between two pads

Fig.5 Failure rate vs. The distance between two pads at each of solder thickness. 


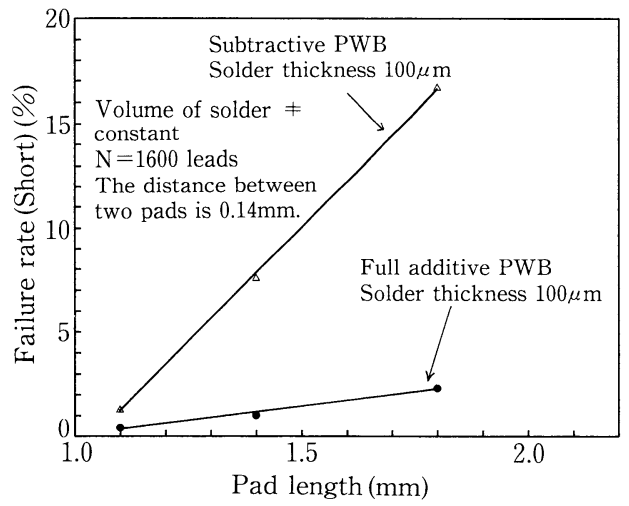

Fig.6 Failure rate vs. Solder thickness.

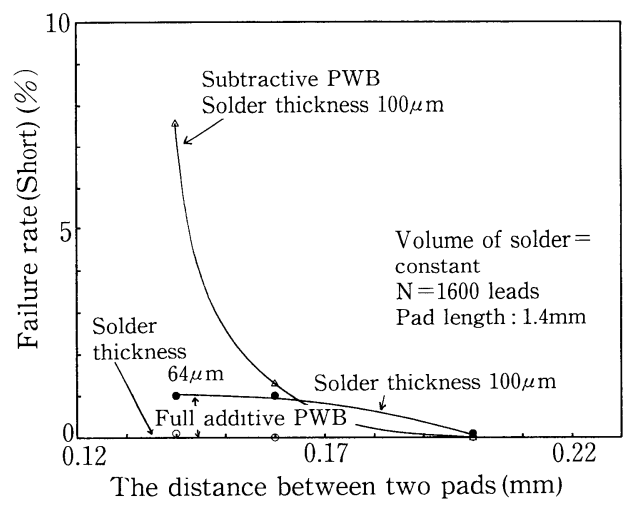

Fig.7 Failure rate vs. Solder thickness.

板はサブトラクティブ基板と比較したとき，パッド幅が 狭いほど，はんだ量が多いほど，ブリッジの発生抑制に 効果があることがわかる。

\section{$4.2 \mathrm{TAB}$ および QFP の必要はんだ量}

TAB 実装用パッドの寸法を一定にして，はんだ供給 量を $10,20,30 \mu \mathrm{m}$ と変化させた基板（ブリッジの無 い状態）へTABを実装し，プルテストによってリード とパッドの間での剝がれの発生度を調べることで，必要 はんだ量の決定を行った。Fig.8にその結果を示す。

はんだ量の増加に従い, 明らかに剝がれのモードの頻 度は減少している。一方，計算により今回使用の $\mathrm{QFP}$ を接合するのに必要なはんだ量は $0.013 \mathrm{~mm}^{3}$ と算出す ることができることから，必要はんだ量を $80 \mu \mathrm{m}$ とし た。TABにおいても同様にして $30 \mu \mathrm{m}$ とした。

\section{3 必要はんだ量の供給}

4.2 でTAB の接合に必要なはんだ量を決定したが, 34

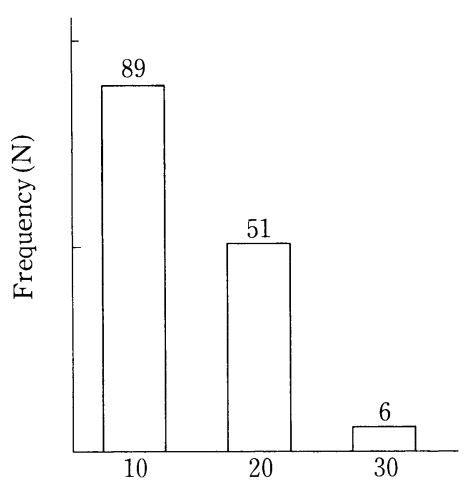

Thickness of solder $(\mu \mathrm{m})$

Fig.8 Frequency of peeled off leads with thickness of solder.

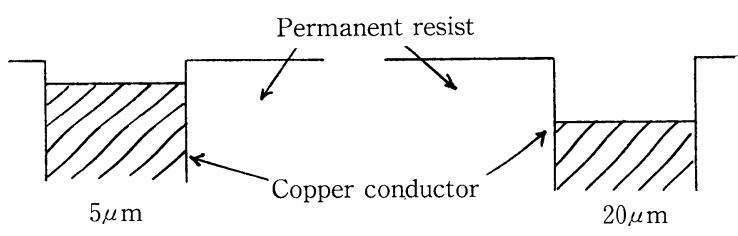

Fig.9 Structure of full additive PWB.

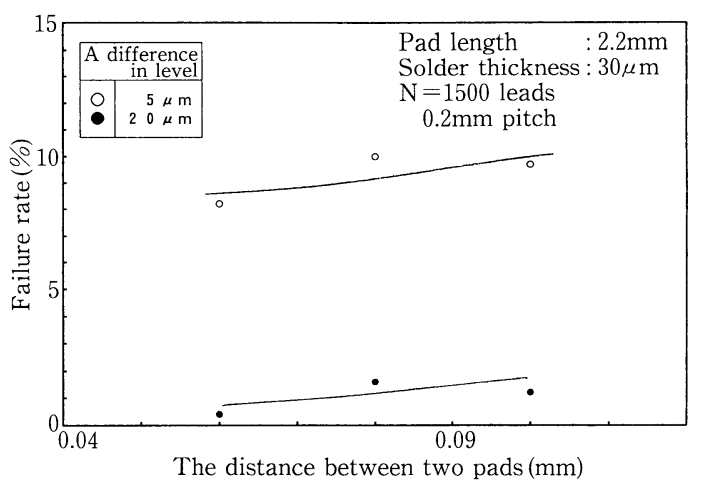

Fig.10 Failure rate vs. The distance between two pads at each of a difference in level.

永久レジストと銅導体の厚みの差が $5 \mu \mathrm{m}$ の状態で必 要はんだ量を安定して供給することは不可能であった。 したがって, Fig.9に示すように，先の厚みの差を 20 $\mu \mathrm{m}$ と大きくとることで永久レジストをはんだに対する ダムとして働かせ，その中にはんだブリッジの原因とな る過剩はんだをパッド上に保持させることとした。Fig. 10 にその結果を示す。厚みの差 $5 \mu \mathrm{m}$ 時に比べはんだ ブリッジの発生率は $1 / 10$ 以下に抑えられ，永久レジ ストによるダムがはんだに対して有効なことが確かめら

$S H M$ 会誌 


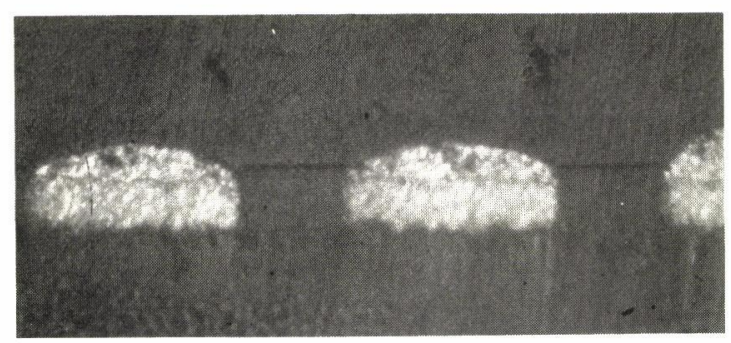

$5 \mu \mathrm{m}$

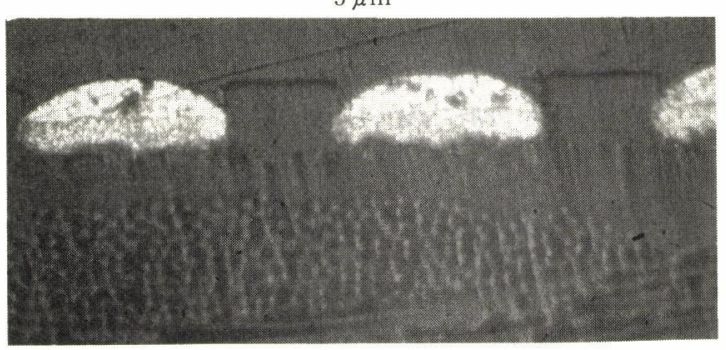

$20 \mu \mathrm{m}$

Fig.11 The cross section at each of the difference. supplied solder.

れた。

\section{5. 評 価}

このようにしてはんだ供給を行った基板に 0.2 ミリピ ッチ，500ピンの TAB を実装した結果は，100ピース 中，はんだブリッジ， TABリードのズレ無し，という 良好なものであった。これに対し，ギャップ5 $4 \mathrm{~m} の$ 基板への実装では，そのおよそ半数にリードのズレおよ びそのズレに起因すると考えられるはんだブリッジが発 生した。Fig.11に，ギャップ $5 \mu \mathrm{m}$ と $20 \mu \mathrm{m}$ のそれぞ れの場合におけるはんだ供給後の断面写真を示す。いず れも上に凸のはんだ形状であるが, ギャップを積極的に 設けた側ははんだ凸部の頂上が永久レジストの高さとほ ぼ同じとなっていることがわかる。このために実装時に 位置合わせされたリードがずれにくくなったものと考え られる。

\section{6. 接合信頼性確認}

\section{1 接合強度}

はんだ接合強度は, ハンディタイプのダイヤルテンシ ヨンを使用し, Fig.12に示す通り，それぞれの方向 ( $\mathrm{TAB}$ ：基板に対して垂直。QFP：基板に対して平行） に部品のリードを引っ張った。

Vol.9, No.6
Fig.13に示すようにリードを引っ張ったときリー ドは引き剥がし力とせん断力に分けられ, ○印に示した ヒ一ル部フィレットに力がかかる。この力に対して, 密 着力（はんだとリード）が等しくなる。これが接合強度 となる。

Fig.14のグラフに 0.2 ミリピッチ TAB を実装したと きの接合強度測定結果を示す。グラフよク，接合強度 $\bar{X}=92.5 \mathrm{~g} /$ ノードである。ほとんどがリード破断モ 一ドで強度が測定されているため, 問題なく立分な強度 が得られていると考えられる。

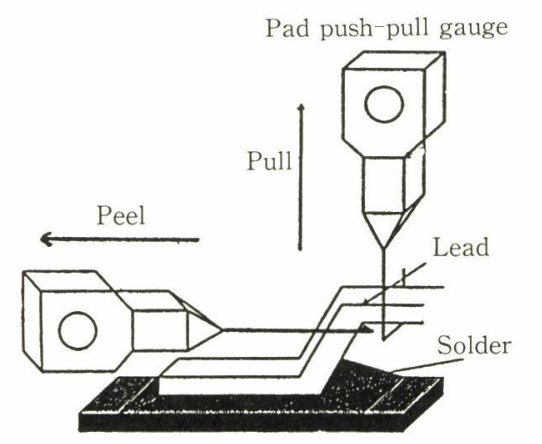

Fig.12 Schematic drawing of a method of test.

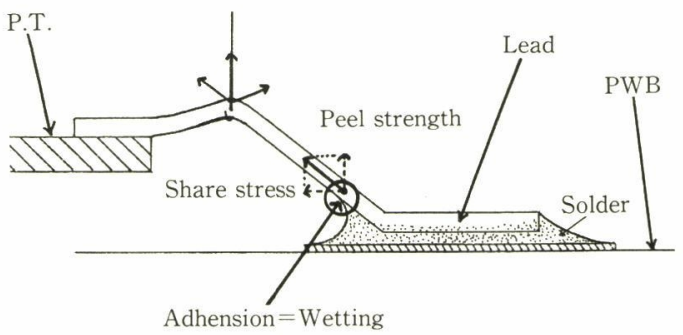

Fig. 13

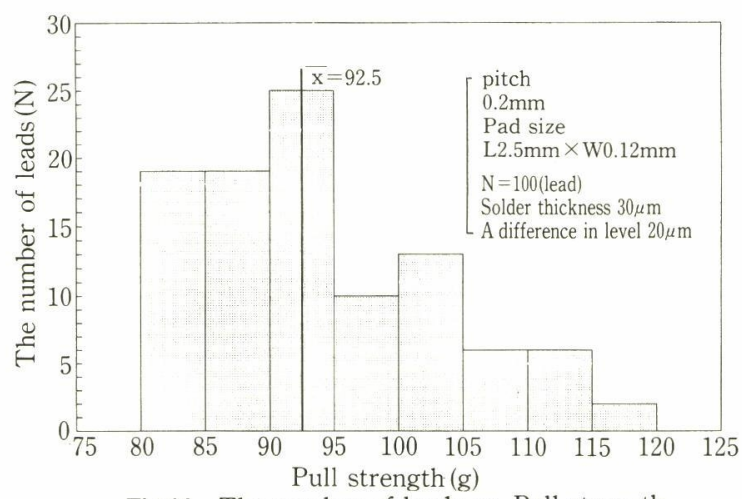

Fig.14 The number of leads vs. Pull strength. 


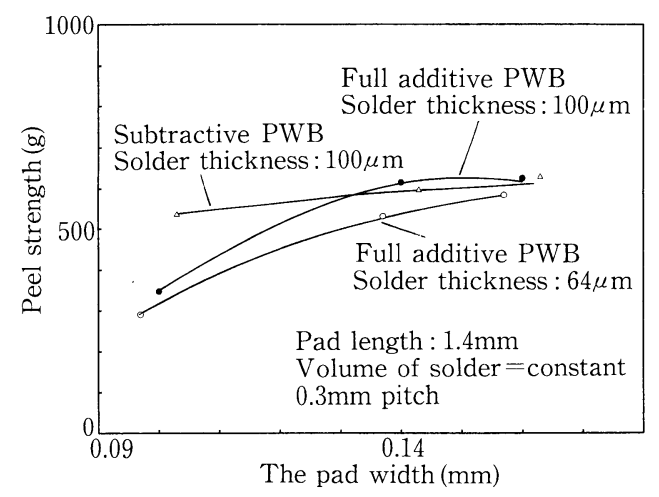

Fig.15 Peel strength vs. Pad width.

Fig.15のグラフに 0.3 ミリピッチ QFP を実装したと きの接合強度測定結果を示す。グラフより，フルアディ ティブ基板使用時の強度は, サブトラクティブ基板使用 時の強度と比較して，同等のレベルといえる（リード幅 に対し，実用パッド設計幅の場合)。また，はんだ厚が 増加することにより，強度も増加するといえる。ただし， はんだ厚が増えても, 強度は $80 \mu \mathrm{m}$ を少し過ぎた当た りで変化しなくなると考えられる。

\section{2 環境試験}

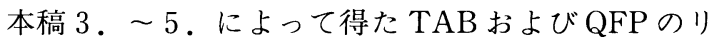
一ドーパッド間のはんだ接合の信頼性を確認するため, 熱衝撃，温度サイクル等の各種試験に供し，引っ張り強 度を測定することではんだ接合の信頼性評価を行った。 試験条件はすべて MIL-STD-883 Cに従って実施した。 Fig.16に TAB（0.2ミリピッチ，500ピン）の熱衝撃 30 サイクル経過後の強度変化を, Fig.17, 18 にQFP $(0.3$ ミリピッチ, 160 ピン) の温度サイクル 500 サイク ルでの強度変化を示す。

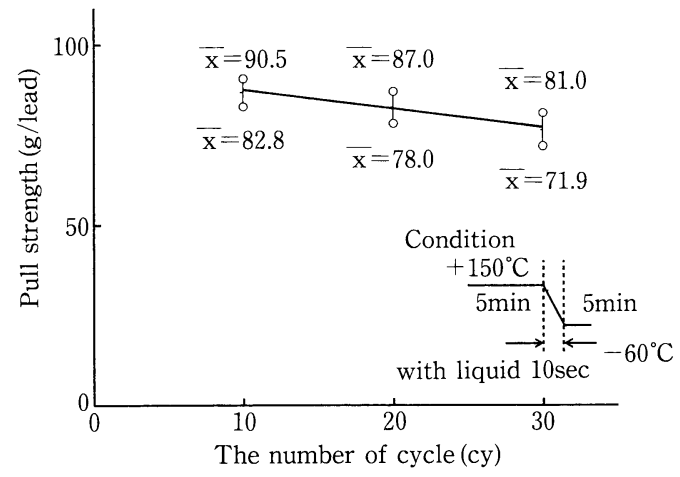

Fig.16 Pull strength after each cycle.
TABの接合において，プルテストにおける破壊モ一 ドはリードとはんだの剝離破壊とリード部破壊とに分け られる。熱衝撃のみに起因すると思われるようなリード の剝離は，ひとつも確認されなかった。平均破壊強度は 熱衝撃 30 サイクルの直後で $10 \%$ 強程度の減少となった が， TABの銅箔自体の降伏強度を考之た場合，実用上 問題ない值であるといえる。

QFP の接合信頼性について，ピール強度は 10 サイク ルまでにほぼ $1 / 2$ 程度までに劣化し，その後はゆるや かに劣化していることがわかる。これは基板とリードの 熱膨張の差からくる応力をはんだ部が吸収し，はんだの 組織が粗大化することで, リードとはんだの界面が脆弱 化するモードが急激に進んだためと考えられる。はんだ 量とパターン幅が 10 サイクル以降の強度に影響してい ることもわかる。さらに，パターンサイズが一定であれ

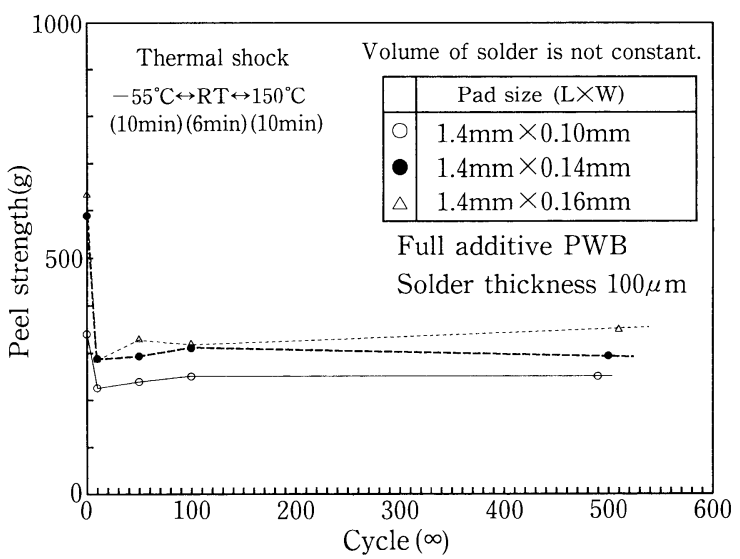

Fig.17 Peel strength after each cycle at each of pad size.

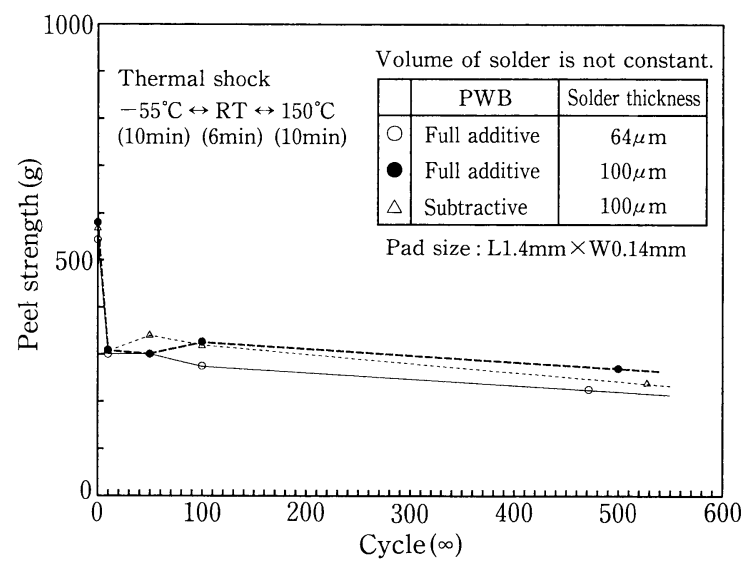

Fig.18 Peel strength after each cycle at full additive and subtractive PWB. 
ば，サブトラクティブ法による基板と何ら遜色ない信頼 性であるということができる。

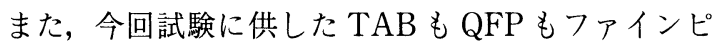
ッチであるため, 高温, 高湿バイアス試験後の絶縁抵抗 の変化率の測定を行った。条件は, $+85^{\circ} \mathrm{C},+85 \%$,

$5.5 \mathrm{~V}$ で，TABがパッド間隔 $0.08 \mathrm{~mm}, \mathrm{QFP}$ が 0.16 $\mathrm{mm}$ で，それぞれワースト值で $2 \times 10^{9} \Omega$ と $2 \times 10^{11} \Omega$ 程度となった。

\section{7. 応用 展 開}

今後，フルアディティブ基板は，その特徵としての，

(1)高密度配線が高精度に形成できる。

(2)表面実装に適合したパッド加工形成ができる。

(3)パターン間の絶縁性にすぐれていることを生かすこ とができる。

分野（たとえば，通信機器，コンピュー夕関連等）を中 心に適用できる。

特に，狭ピッチのみならず，0.5 QFP 実装でも問題 となっていることは少なくない。そこで, 実装方式 （TAB 実装または QFP 実装）を充分に考えた上で，実 装コス卜低滅推進のため，実装步留りに影響を与える実 装条件としてのはんだ供給，パッド設計，その他基板設 計を, 基板の利点を生かしながら設定する。たとえば, 永久レジストをダムとして利用した一文字印刷法による はんだ供給（はんだ厚みのバラツキが抑えられる），適 性はんだ量を考えて設計したパッド寸法, 基板表面平坦 さを充分生かしたソルダーレジスト等の設計があげられ る。これらをべースにした提案ができることが，今後の 課題である。

さらに, 狭ピッチ部品実装の実現と高密度配線ルール で，基板設計の自由度向上（層数の低減 8 層 $\rightarrow 6$ 層等） による低コスト化の実現も可能である。

\section{8.まと め}

アディティブ基板ではファインなピッチのパッドに従 来の一文字印刷法で簡単にはんだが供給でき，その量を コントロール可能なことを確認した。これは, ファイン ピッチのパッドへのはんだ処理が, 電解メッキ法や特殊 なはんだコート方法無しに従来方法によって充分可能な ことを意味し, 特殊な工程がなくなり, コス卜的にも有 利であるといえる。

今回示した信頼性データより, サブトラクティブ法に よる基板と比べても何ら遜色のない性能である。また, 従来よりアディティブ法の欠点とされてきた諸問題が解 消された現在, むしろアディティブ基板はそのファイン ピッチ形成能力, 高歩留性, その他において, $\mathrm{TAB} お$ よび将来の狭ピッチ部品を実装する $\mathrm{MCM}-\mathrm{L}$ 用基板と してすぐれた性能を示した。

現在，アディティブ基板のポテンシャルをさらにつっ こんだ形で定量的に評価中であり，今後の課題としては， 前述の永久レジスト〜銅導体間のギャップが SMD 部品, 特に 1005 サイズのチップの実装性, 接続信頼性に及ぼ す影響を検討するとともに, さらにファインな部品の実 装についても検討して行く予定である。

\section{文献}

1) United States Patent: "Package for Surface Mounted Components" , IBI JAPAN

2）榎本：電子材料,「高密度・高信頼性フルアディティブ配線 板」, 別冊 (Oct.1988)

\section{〔執筆者紹介〕}

脇原義範 (わきはら よしのり)

昭和 63 年岐皁大学工学部電子工学科卒業。同年, イビデン (株入社。以来, 実装技術の開発に従事。

森茂樹 (もりしげき)

昭和 63 年群馬大学工学部化学工学科卒業。同年, イビデン (怢入社。以来, プリント板の開発に従事。 